\title{
Political geography and palatial Crete
}

Andrew Bevan

Postprint of 2010 paper in Journal of Mediterranean Archaeology 23.1: 27-54

(doi: 10.1558/jmea.v23i1.27).

\begin{abstract}
The political geography of Crete during the period of the Bronze Age palaces has been a subject of widespread debate, not only with respect to the timing of the island's move towards greater social and political complexity, but also with regard to the nature of the political institutions and territorial configurations that underpinned palace-centred society, as well as their longer-term stability over the course of the $2^{\text {nd }}$ millennium BC. As such, the region provides an ideal context in which to consider the broader question of how we develop robust political geographies in pre- and proto-historic contexts. This paper proposes the need for a more deliberate interlocking of computational, comparative and material approaches, as a means of guiding our political model-building efforts.
\end{abstract}

\section{Introduction}

While the world of palatial Crete has no foundational story as powerful or as enduring as the Trojan war, the Classical tradition nonetheless invokes the Cretan palatial past in conveniently clear-cut ways, referring to a central mythical figure of King Minos alongside stories of political unification, lawgiving, overseas expansion, thalassocracy, internecine struggle and eventual political re-fragmentation (e.g. Homer Odyssey 19.165-202; Herodotus Histories 1.171-3, 3.122; Thucydides Peloponnesian War 1.4-8; Aristotle Politics 2.10; also Pseudo-Apollodorus Bibliotheca 3.1-3). More precisely, such sources assume the development of a single state under a male king whose core political borders encompassed all of Crete and whose wider political control by indirect governance eventually extended to at least some of the Aegean islands. Arthur Evans' reconstruction of a priest-king on the throne at Knossos (e.g. 1921: 1-5) clearly drew much inspiration from these earlier conceptions, but added to them some of the interpretative priorities of his own Victorian and Edwardian time and eventually created a vision of Minoan politics and society that is still very much present in the public imagination today (Morris 1992: 150-194; McEnroe 1995; Papadopoulos 2005; Momigliano 2006).

In historical terms however, Proto- to Neopalatial Crete (ca.1900-1450 BC, see figure 1 for the chronological divisions throughout this paper) remains one of the complex societies in the Bronze Age eastern Mediterranean about whose political character we know least. The lack of deciphered written documents is of course one contributing factor, and moreover, while the rich visual imagery and artistic production of Middle and Late Minoan Crete are far more prolific than in many contemporary eastern Mediterranean societies, strangely they offer no strong sense (at least to the uninitiated modern viewer) of ruler iconography or direct textual explication (Davis 1995). In combination, these absences mean 
that we do not have convenient evidential shortcuts for understanding Cretan political geography. More positively however, they encourage us to consider, more carefully than we might otherwise do, how such processes might manifest themselves in archaeologically recoverable ways.

This paper contributes to such an effort by arguing for a more deliberate interlocking of computational, comparative and material approaches, as a means of guiding our political model-building efforts. However, partly as a justification for the models discussed below, it is first worth revisiting some awkward aspects of political terminology. For example, a great deal of attention has been paid to the formation and workings of the 'state' in past and present complex societies, with the term typically implying an independent or near-independent political unit that wields legal, military and economic authority over a designated group of people, their resources and the landscape they inhabit (Carneiro 1970: 733; A. Smith 2003: 152-83). Although there are serious drawbacks to casting states as the exclusive protagonists in any historical narrative (Wolf 1982: 7-9) and tremendous variation in the degree to which state powers are centralised (e.g. Gledhill 1988; M. Smith 2005: 834-5), states nonetheless represent an important unit of cultural analysis.

The establishment of any kind of political authority beyond a certain demographic scale, such as that associated with states, is likely to require at least some minimal level of hierarchical re-ordering and can be thought of as a form of organised cooperation in which one kind (or scale) of political agent is empowered to exert authority in decision-making over another (Lake 2009). Individuals can exercise hierarchical political authority over each other, but similarly structured relationships also exist amongst larger groups, organizations and states. Typically, people are more accepting of political hierarchies with an institutionalised quality, those that have gained legitimacy through broad social consensus and as part of an enduring historical or cultural tradition. People also coordinate their hierarchical personal relationships through a set of stylised social cues-usually involving the choreography of time, space and force (Fiske 2004; e.g. the spatial order in which politicians sit around a table or the temporal one in which they file into a room). The spatial, temporal or contextual 'reach' of a particular individual or institution's authority is usually a good rule-of-thumb measure for their place in the political hierarchy.

However political agents need not always be linked into wholly dendritic, hierarchical networks of power and in fact can enjoy overlapping and sometimes contesting political authorities, This is often called a heterarchial structure (e.g. Crumley 1995) and such forms of coalition and competition have been proposed for Bronze Age Crete as for many other early complex societies, particularly with eye to the role of political factions (e.g. Hamilakis 2002; Schoep 2002). It is certainly true that for Crete, even the use of the term 'palace' to refer to the elaborate court-centred complexes at sites such as Knossos, Malia and Phaistos involves a potentially unwarranted set of political assumptions (Driessen 2002), given our uncertainty about the nature of ruling authority on the island and the fact that some smaller-scale elite buildings also exhibit some perceived 'palatial' features. 
However, while complex behaviours demonstrably emerge from wholly heterarchical structures in other fields of enquiry, it is, comparatively speaking, almost impossible to identify well-documented examples of complex political units that are entirely heterarchical in nature (not even those communist states, modern democracies or leagues of nations that are avowedly heterarchical in design). Most well-developed case studies in fact emphasise that heterarchical networks extend, renegotiate and fit within certain power hierarchies rather than replace them entirely (e.g. Ehrenreich et al. 1995; Schoep and Knappett 2004). In this respect, there is a risk that, if we place near-exclusive explanatory emphasis on the politics of heterarchy, factionalism, feasting and individual agency, we throw out clear-cut, cross-culturally justifiable structures of higherlevel political organisation, in favour of a host of insightful, but fundamentally non-substitutable social properties.

So the discussion below retains an emphasis on states and palaces, and on understanding political hierarchy, while emphasising the continuing need to investigate the ways in which this power is subverted, devolved, duplicated and/or compartmentalised. One obvious manifestation of the place of an institution in a political hierarchy is the extent to which its political authority is made tangible across the physical landscape (Cherry 1987). We usually refer to this spatial reach as a form of territoriality. Again, there has been lively debate about the character of political territory in the Bronze Age eastern Mediterranean and Middle East (e.g. Hamilakis 2002: 184-5, Casana 2009) as in other regions (see M. Smith 2005). In particular, there is a growing contention that we cannot simply impose our own modern territorial perspectives and methods of territorial analysis on Bronze Age realities, and that, in any case, the degree of political centralisation varies tremendously. One important further contribution of this critique has been its emphasis on the fact that there are styles of spatial recording-keeping ('geo-metries' as John Bennet nicely calls them with regard to later periods, 2007) that differ in important ways from the cadastral, map-like representations with which we are familiar, and that engender alternative ways of thinking about political and economic space. However, a less helpful suggestion is that, in some sense, territoriality itself is a wholly misleading notion. I would argue that this more extreme deconstruction misleadingly conflates our own modern uncertainty about past territorial concepts (driven by very partial survival of the right kinds of evidence) with actual past uncertainty. In this sense, the invocation of a pre-modern, deterritorialised 'other' as an antidote to the simplistic application of modern 'common sense' is directly analogous to disciplinary debates over Bronze Age commerce (see Bevan 2007: 21-29). In both cases, while the revisionism is a healthy measure in the shorter term, we lose a great deal by denying any conceptual or methodological common ground.

The discussion below therefore attempts to navigate these theoretical issues by integrating a range of computational and empirical approaches. It begins by reasserting the need for baseline models of territoriality that address the impact of human travel, landscape stratification and settlement competition and that are also comparative in scope. These models are not explanations themselves but 
suggest spatial scales and thresholds that are useful to think with when reconsidering patterns in Cretan material culture. The final sections of the paper then concentrates on two types of material culture-one static and large-scale, the other portable-and considers how these may have been politically manipulated.

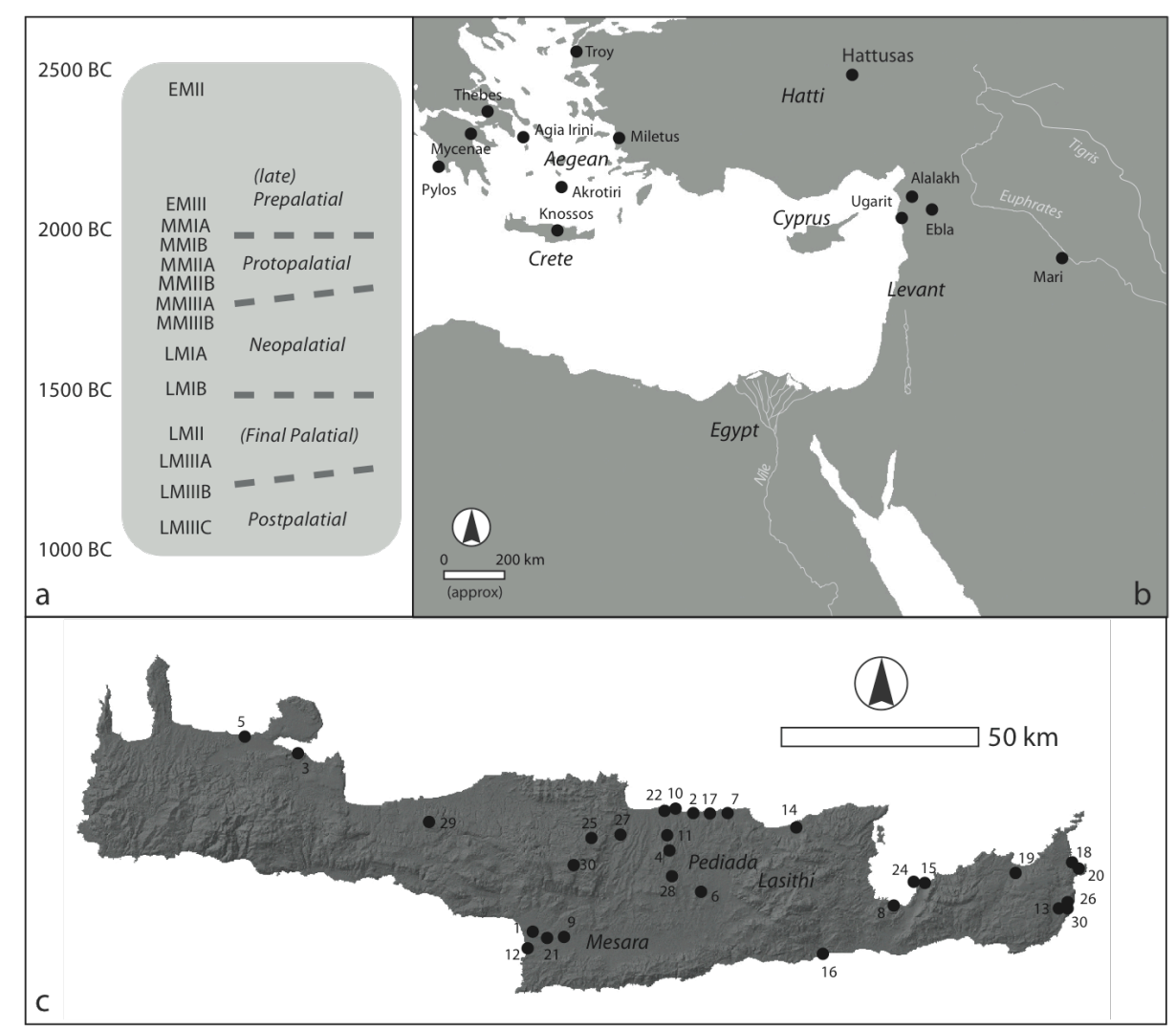

Figure 1. a) A guide to the chronological terms mentioned in the text (EM= Early Minoan, $\mathrm{MM}=$ Middle Minoan, $\mathrm{LM}=$ Late Minoan), and maps of $\mathrm{b}$ ) the eastern Mediterranean and c) Crete, with sites mentioned in the text. Cretan site numbers are: Agia Triada (1), Amnisos (2), Aptera (3), Archanes (4), Chania (5), Galatas (6), Gournes (7), Gournia (8), Kalyvia (9), Katsambas (10), Knossos (11), Kommos (12), Koukou Kephali (13), Malia (14), Mochlos (15), Myrtos Pyrgos (16), Nirou Chani (17), Palaikastro (18), Petras (19), Petsophas (20), Phaistos (21), Poros (22), Prasa (23), Pseira (24), Sklavokambos (25), Traostalos (26), Tylissos (27), Vathypetro (28), Vrysinas (29), Zakros (30), Zominthos (31).

\section{Computational Approaches}

\subsection{Travel Times}

The first section begins, perhaps rather prosaically, by seeking to model typical pedestrian travel times on Crete. On a rugged island such as Crete these are potentially more informative about the reality of political control than straightline, as-the-crow-flies distances. Compared with other terrestrial environments where variable land cover and seasonal variations play a much larger part, Crete provides a relatively simple environment for modelling terrestrial movement, at least prior to the use of mechanized transport, having few if any navigable rivers 
and only a limited number of really impassable forested zones or thickets. Cost surface analysis is a technique that has been applied in archaeology and other disciplines with somewhat mixed success in the past, but if used carefully and empirically validated, it can provide a substantially more subtle perspective than straight distances (see Conolly and Lake 2006: 214-225). ${ }^{1}$ Figure 2 compares computed pedestrian travel times with those recorded by John Pendlebury (1939; see also Grundon 2007) for 60 journeys made by foot across Crete prior to the advent of major mechanised transport and road-building projects. Both the computationally predicted and historically-documented times are directional in the sense that the route and time from A to B is not the same as from B to A due the fact that different costs are involved depending on the direction in which the terrain is traversed (technically known as an anisotropic cost surface model). In any case, while the computed times shown in figures 2 are sometimes a little too rapid for journeys over eight hours (reflecting both some continuing methodological issues and the fact that real world travel for more than a day usually requires extra time for rest-stops, overnight stays, etc), the correlation with all other real-world journeys $\left(r^{2}=0.96\right.$, and better than as-the-crow-flies correlations, $p<0.005$ ) suggests a promising platform for considering other Cretan travel patterns.

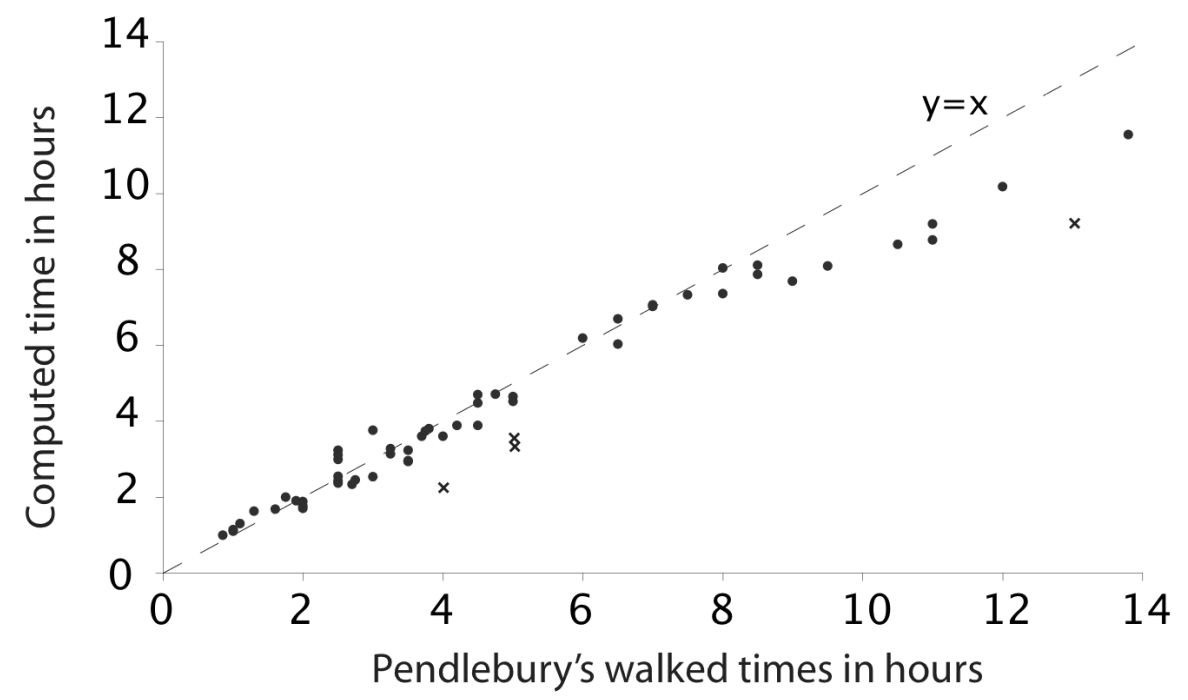

Figure 2. Comparison of the times recorded by Pendlebury for his walks between Cretan sites $(n=60)$ and those computed by anisotropic cost surface analysis (suggested outliers are marked as crosses).

Figure 3a therefore presents a computational model of travel times out from Knossos to all other parts of Crete. It is interesting to compare this to Bennet's discussion (1985) of the toponym groups identified among the LMII-III Linear B tablets, in which Knossos seems to dominate much of the central part of the island and arguably as far west as Chania. Most of the common toponyms fall

\footnotetext{
$1_{1}$ The geographic analysis here draws on a relatively fine-scale $15 \mathrm{~m}$ digital elevation model of Crete (Chrysoulakis et al. 2004), an anisotropic cost surface algorithm in GRASS GIS (r.walk, using default slope parameters and knight's case search; see Fontenari et al. 2005) and a recently-developed Xtent module (r.xtent, see Ducke and Kroefges 2008)
} 
within a neighbourhood around Knossos of an overnight or long day's trip (toponym groups I-III), except in the west where Chania and Aptera are much further afield by land. Figure $3 b$ therefore considers the possible effect of sea voyages. Maritime travel is sometimes a rather risky business in the Aegean, one usually conducted by a knowledgeable few and prone to important diurnal, seasonal, directional and technological variations (e.g. Casson 1951, and for Cretan coastal transport: Faure 2000). However, even if we assume an opportune, but not unusual, speed at sea which is twice that typical of pedestrians (ca. $10 \mathrm{~km}$ or 5.4 knots), the computed results suggest that travel times out from Knossos to the far ends of the island would have been drastically reduced (Figure $3 \mathrm{~b}$ ). More generally therefore, for those who could afford to engage in such seaborne activity regularly or on a large-scale (in Crete's later history, these were often outside maritime powers such as Rome, Byzantium, Venice and Constantinople: Bennet 1990), maritime transport had the effect of warping the spatial configuration of communities on Crete even further.

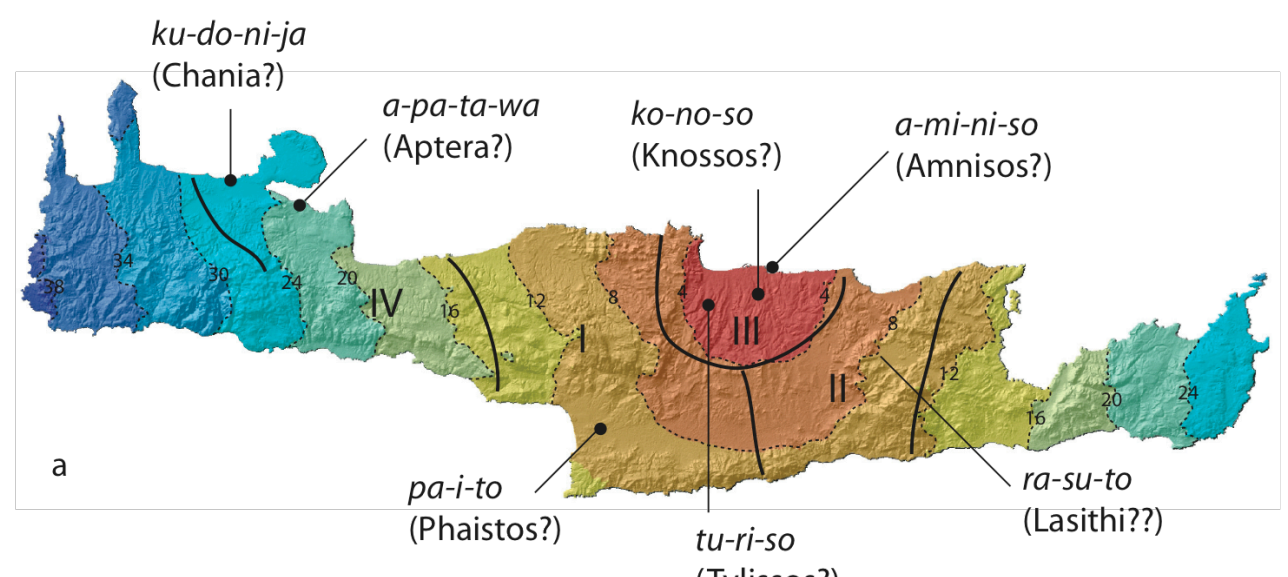

(Tylissos?)

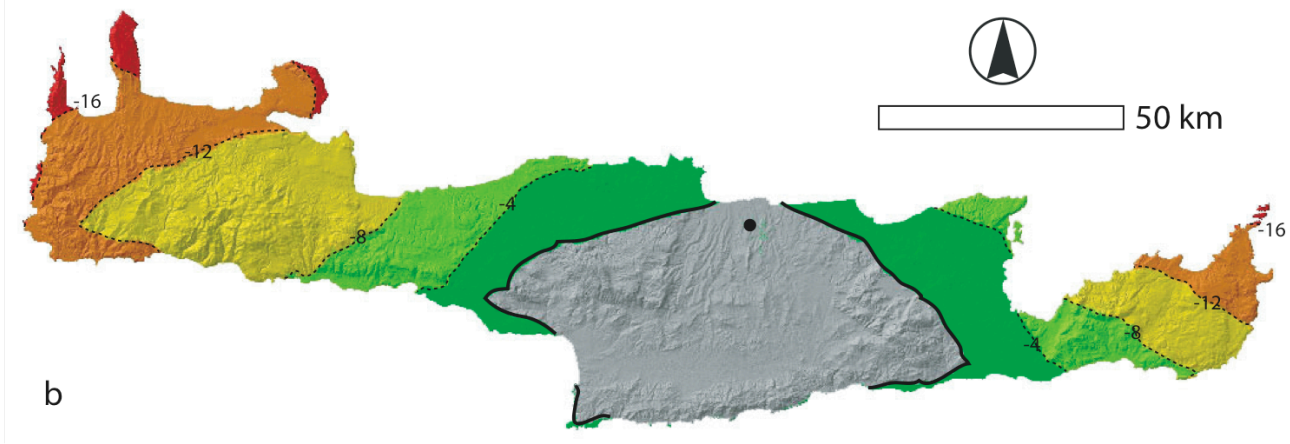

Figure 3. Anisotropic cost surfaces from Knossos: a) terrestrial travel times (dotted lines are 4 hour contours outwards from Knossos), along with the toponym groups suggested by the Linear B archives (solid lines are very rough group divisions after Bennet 1985: fig.iii.4), b) a rough impression of the time saved by including a maritime leg in the trip from Knossos. The negative values refer to the number of fewer hours needed to travel to that location by comparison to figure 3a above (assuming no embarkation delays). Dotted lines are 4 hour contours and the solid line marks the area with no change. 


\subsection{Territorial Allocations}

The above approach can also be used to refine baseline models of territorial competition between neighbouring sites. Perhaps the most common type of territorial model used by archaeologists so far has been one in which the entire landscape is shared out evenly amongst sites of roughly equal status (i.e. what are know as Thiessen polygons or a Voronoi tessellation). Such a baseline model of 'peer polities' has in fact proved to be a potentially key feature in the development of early complex societies (Cherry 1986) and this section therefore begins by exploring possible early peer-polity interactions on Crete and then moves on to consider, first, the possible expanding catchments of major sites and second, more explicitly hierarchical models of political territory. Figure 4 suggests the territory that might be allocated to each of three major palatial sites in central Crete, were we to assume that they exerted roughly equal political or economic influence (see Knappett 1999 for evidence for the extent of one these possible Protopalatial polities is the Malia-Lasithi region). The zones of uncertainty in this figure (shown with double question marks) are those whose allocation to a particular palatial site changes depending on whether we use a cost surface model that models directional travel (an anisotropic approach, as above) or one that does not (an isotropic approach which is often less useful, but possibly relevant here for assessing multi-directional flows of people and goods). In such potentially contested places, local affiliations might well vary depending on what form of interaction was involved, and a good example of this might be the area around Gournes, where various commentators have mentioned the very mixed Knossian and Malian stylistic references of the decorated Protopalatial pottery (e.g. Cadogan 1994: 61). A useful research agenda for the future would certainly also demand closer attention to the Bronze Age occupation histories of potential axial locations in-between the sometimes dominant neighbouring centres of Knossos, Malia and Phaistos (or indeed across the whole Pediada region: Rethemiotakis and Christakis 2004).

Interestingly, if we also trace the routes between Knossos and Phaistos that are likely to be most time-efficient (both to and from), they match well with Arthur Evans' delineation of a Bronze Age 'Great South Road' (1928: 60-81). For Evans, this was part of an organised island-wide road network, a sign of unified political power, and part of a Knossian desire to use the southern Mesara and Asterousia ports as a direct link to Egypt across the Libyan Sea. The relevance of these Egyptian connections can be strongly questioned on many grounds, and the evidence for the Bronze Age road itself has never been properly revisited archaeologically. Even so, the analysis here does suggest that this was indeed a key arterial route between the north and the Mesara plain. It possibly also dovetails with the geographical location of a set of Linear B toponyms associated with deliveries of coriander for the LMII-IIIA perfumed oil industry (Knossos Ga2 series, Melena 1974). 


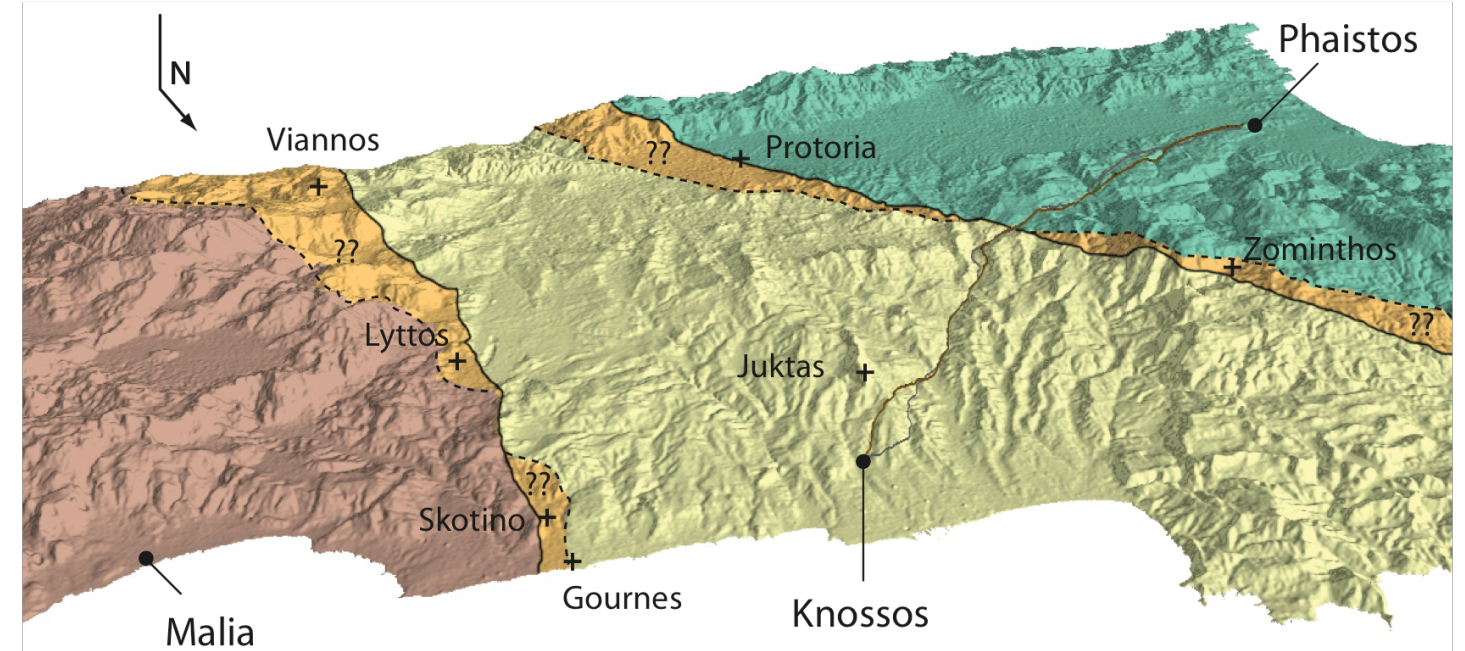

Figure 4. Perspective view of possible territorial allocations for three major central Cretan palaces, based on travel time: Knossos, Phaistos and Malia. The black line represents the border drawn between them where the computed travel costs are anisotropic, while the areas with double question marks indicate those zones whose affiliation changes when an isotropic model is used. The anisotropic least cost routes from Knossos to Phaistos and in the reverse direction are also shown. A few other locations have been added for context.

We can also use computed travel times to consider the agricultural catchment that Knossos might need as its population grew over the course of the Bronze Age (Figure 5). One important cross-cultural threshold associated with human travel budgets is that most people spend about an hour of their time traveling each day (Zahavi 1979; Marchetti 1994). However, as the population of any single centre rises into the thousands, the agricultural landscape it draws upon will rapidly cross this threshold and diversify into a pattern of dependent farms, hamlets and/or villages that provide surpluses in return for other services. This process of landscape stratification is crucial to the development of early states, and it is no surprise that the early Cretan palatial centres emerge, out of a host of other possible candidates, in the best lowland agricultural zones on the island (despite Early Bronze Age Aegean trading patterns that might superficially have suggested other evolutionary pathways: Whitelaw 2004b). In the Knossos valley this particular process of landscape stratification should have begun at least by EMII (as opposed to more general patterns of social and economic stratification that some have argued begin in still earlier periods: e.g. Tomkins 2004) and intensive survey of the urban site documents rapid population increase over the late Prepalatial period, continued if perhaps slower growth thereafter and a city which reached an extent of at least 65 ha by the Neopalatial, with a possible population of 14-18,000 people (Whitelaw 2004a: 153). Very roughly, we could assume that each resident would require about a hectare of flatter land to sustain them (for a slightly lower estimate, see Warren 2004: 165). If we map a series of travel times out from Knossos that would be necessary to access various amounts of better flat land for agriculture, the results suggest strongly that, by the beginning of the palatial period at the latest, the demands of this larger urban centre would have been impinging directly on the possible land holdings of neighbouring centres such as Archanes. Indeed, as Todd Whitelaw has suggested 
(2004: 153-4), the building sequence at the Archanes Phourni cemetery arguably reflects such a demographic crunch, with the considerable construction activity it experiences in EMIII-MMIA perhaps suggesting both local prosperity and a spirit of inter- and intra-community competition, but followed by far less activity in MMIB-II when we might suspect that Archanes' ambitions and resources were increasingly subordinated to Knossos. It is arguably also during this late Prepalatial-early Protopalatial period of increased urbanisation that we might expect experiments with more intensive land management practices such as terracing (e.g. Krahtopoulou and Frederick 2008).

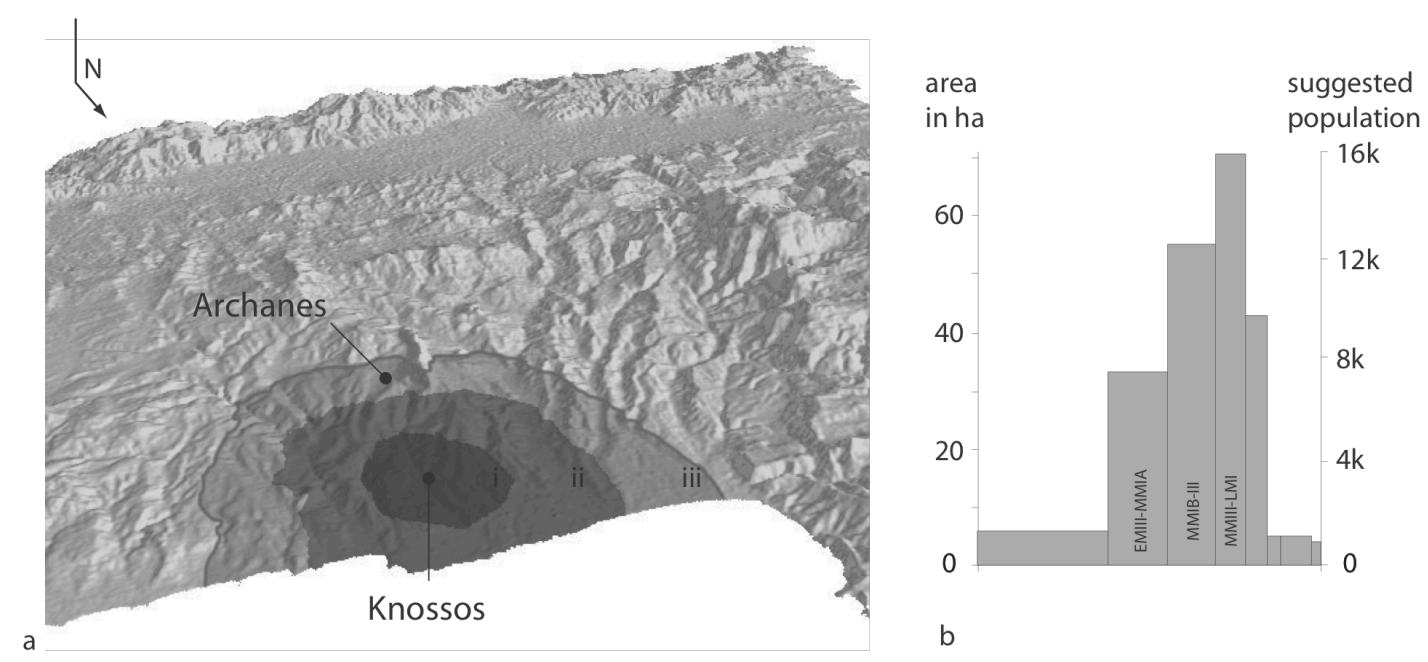

Figure 5. The expansion of Knossos and its hinterland: a) a perspective view of the travel distances from Knossos needed to access i) 2,000 ha, ii) 8,000 ha, and iii) 14,000 ha of better agricultural land (assumed here to be terrain of less than $12^{\circ}$ slope); b) a chart of the changing extent of the Knossos town over the Bronze Age, along with suggested population estimates (after Whitelaw 2004a: fig.10.8).

\subsection{Hierarchical Models}

So far we have considered only the equal sharing out of territory amongst centres of presumed equal status. Of course, real world political and economic landscapes also reflect patterns of hierarchical dominance among sites and there are several ways that these might be modelled computationally (e.g. Rihll and Wilson 1991; Graham and Steiner 2006; Evans et al. 2009). One convenient approach given the nature of the Cretan data was first proposed by Colin Renfrew and Eric Level (1979, typically referred to as an Xtent or tent model). It suggests that the political influence exerted by a particular site at any given location in the landscape can be modeled as a function of the relative size of the site and its distance away from that location of interest, with patterns of intersite dominance then assessed by identifying the site with the largest influence at any given location. 

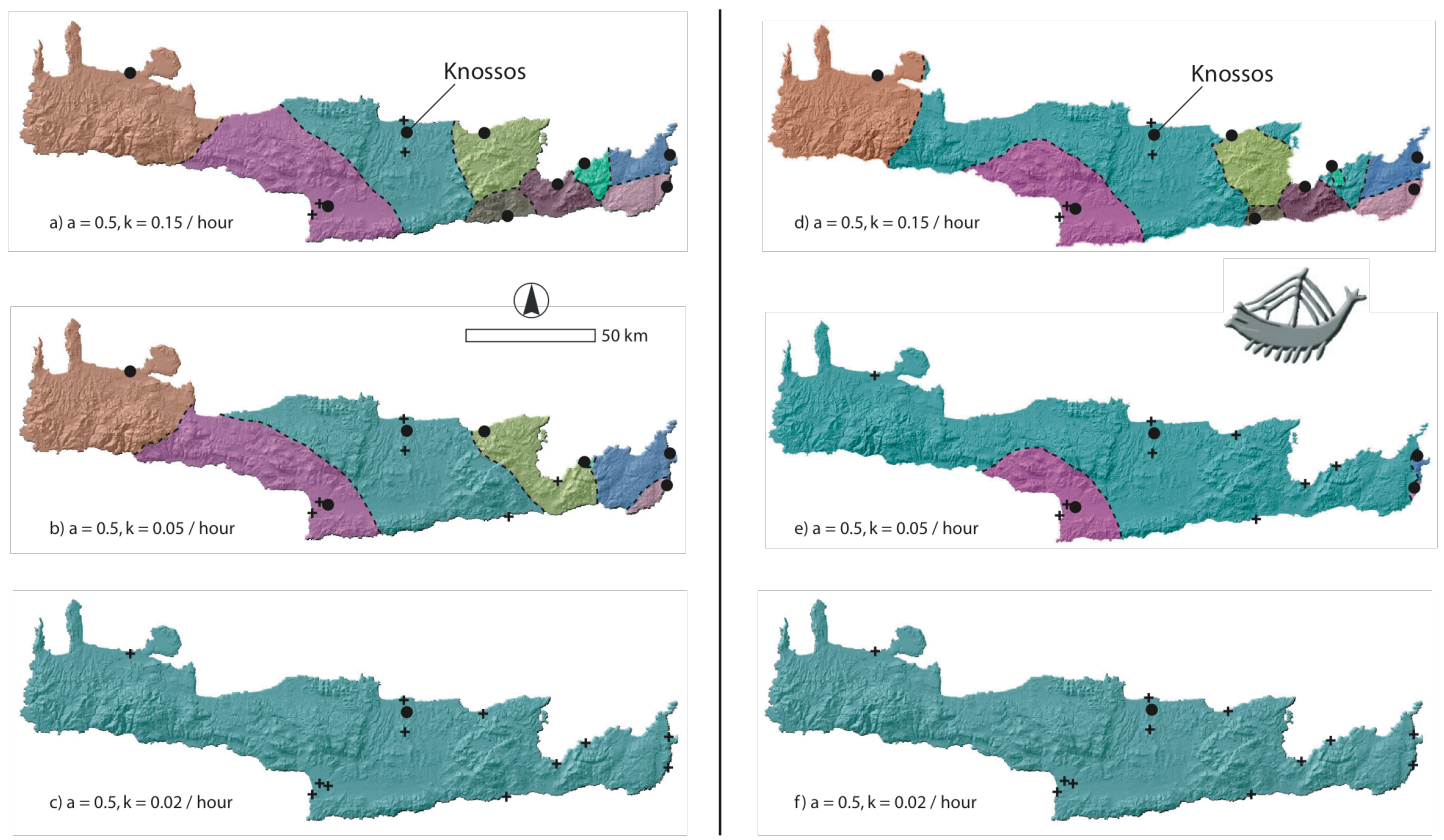

Figure 6. Six cost-weighted territorial allocations according to the Xtent model: a-c) terrestrial travel only, d-f) maritime travel allowed for Knossos only (at $5 \mathrm{~km} / \mathrm{hr}$ ). Dominant centres are shown as solid circles and subordinate ones as crosses.

The cost surface results discussed above allows us to implement a topographically-sensitive version of this model and figure 6 displays the results for three different distance decay values, bracketing those found useful by previous studies. ${ }^{2}$ Interestingly, they offer almost the full gamut of plausible political outcomes, from segmentary states (for this pattern in Archaic-Classical Crete, see Perlman 1992; see also Soetens et al 2003: 486, pl.cvi.b) to complete control by the palace at Knossos, with the added impression that any shift between these two possible extremes is quite abrupt. In fact, the current model assumes that the most egalitarian possible size relationship between Knossos and its largest competitors and relatively small downward changes in the size for the less-well defined Neopalatial sites at Phaistos and Malia are sufficient to induce patterns of greater Knossian dominance. Likewise, any major

2 The traditional Xtent equation is $\mathrm{I}=\mathrm{C}^{\alpha}-\mathrm{k} . \mathrm{d}$ where, at a given location in the landscape, the influence exerted by a particular site (I) can be expressed as a function of the relative size of a site $\left(\mathrm{C}^{\alpha}\right)$, and its distance away from the location of interest (k.d). The exponent $\alpha$ is used to reweight site size (i.e. either amplifying or dampening down relative size differences) while $\mathrm{k}$ models the rapidity with which influence decays with increasing distance (for simplicity, the model used here follows previous ones in using this linear decay function although an exponential or negative logistic decay might be more appropriate). Ideally, both of these weighting variables should be determined empirically by assessing them first in known political contexts and similar socio-economic circumstances. However, there are both practical and theoretical justifications for using 0.5 as a working default value for $\alpha$ (e.g. Renfrew and Level 1979: 157-8), and several commentators have also explored $\mathrm{k}$ values that express a decline in influence of between $0.5 \%$ and $3 \%$ per kilometre of horizontal distance traveled (Grant 1986: 21-24; Renfrew and Level 1979: 151-166; Scarry and Payne 1986: 83-4). For figure 5, this bracketed range was transformed into travel time values between $2 \%$ and $15 \%$ per hour (assuming the standard estimate of unimpeded travel on the flat as ca.5km/hr). As in previous studies, site sizes were used as proxy for individual site influence and were first standardised by dividing by the size of the largest centre. 
improvement in the efficiency of communication across the island is also likely to have promoted the centralising ambitions of the largest centre, particularly if you assume unequal access to these new travel opportunities. A good example might be the construction of a formal road network or differential access to a maritime fleet. Taking the latter as an example, if we allow Knossian influence to spread not just by land but also by sea (using the estimate for maritime travel used in figure $3 \mathrm{~b}$ ), the results change dramatically (figure 6d-f), with a far more efficient propagation of political power to the far ends of the island. Differential maritime control may therefore be a key issue as, not only is there a strong, if highly speculative, later tradition of an active Knossian fleet (the thalassocracy of Minos': e.g. Hägg and Marinatos eds. 1984; Knapp 2003; Niemeier 2004), but in historically-documented periods prior to its inclusion into the modern Greek state, Crete has only been controlled as a single unit by those that did so through naval power, and from a local base near the north-central coast (Rome, Venice and Constantinople; notably all external states however: Bennet 1990).

\section{Archaeological Approaches}

\subsection{Previous Emphasis}

The preceding sections have so far stressed topography, subsistence and demography as baseline factors that commonly structure the size and extent of political territories. Not yet addressed in any great detail however has been what the material culture of Bronze Age Crete itself might offer in terms of insight. In particular, the discussion below shifts slightly in focus to concentrate for the most part on the Neopalatial period where our range of evidence is greatest and the argument for certain, contingent patterns of centralisation most persuasive.

There are many different aspects of material culture that might conceivably offer purchase on political divisions. For example, discrete regional variations in pottery style can certainly be used to trace production and consumptions strategies, and may sometimes also suggest political affiliations, though such arguments have to be made in a very case-specific and contextual way (for a good discussions, see Knappett and Schoep 2000; Knappett 2002). Another promising approach is to pay close attention to the vicissitudes of individual site construction phases that in palatial Crete clearly suggest contrasting highs and lows (e.g. Warren 2004: 163-4) and may well reflect changing political conditions. Peak sanctuaries provide a further distinctive feature of Cretan palatial ritual practice that may express changes patterns of political authority, not least because they: (i) often overlook important tracts of agricultural or pastoral land, (ii) decrease rapidly in number from the Protopalatial to Neopalatial and gain much closer links with major palatial centres and (iii) are possibly exported in a particularly Knossian version to other parts of the Aegean (Peatfield 1987; Watrous 1996: 75-9, 97; Soetens et al 2002; Bevan 2007: 131$3)$.

Apart from pottery, site histories, and peak sanctuaries, it is sealing and administrative practices that have been a key point of emphasis so far for the study of Cretan political geography. The most well-known case made so far has 
been on the basis of a series of 'look-alike' sealings that were made from impressions similar-looking (and sometimes identical) gold rings and have been found widely across Crete and off-island at Akrotiri (Betts 1967; Hallagher 1996: 207-13; Krzyszkowska 2005, 167-8; see also Schoep 1999). These sealings were made on flat-based clay nodules, with markings of fine, knotted cords on the underside, suggesting that they sealed wrapped leather documents. There is general consensus that these point to an upper, island-wide tier to the administrative system(s) on LMI Crete, but debate remains over whether their iconographic consistency reflects i) shared elite culture and inter-polity communication or ii) was meant to authenticate the power of officials within a single polity (usually assumed to be Knossian) across much of the island, and perhaps beyond. In any case, their presence also coincides with the decline of direct object sealing practices on Crete (Weingarten 1990: 112-4), which might suggest a scaling-up of administrative interest over longer distances at the same time as a transformation of the way transactions were recorded within the immediate resource hinterlands of individual palaces.

Here the focus is placed on three other, potentially complementary, perspectives. The first considers comparative evidence from other Middle to Late Bronze Age polities in the eastern Mediterranean in order to obtain some purchase on the likely character and spatial scale of political authority. The second and third return to the detail of the Cretan archaeological record, particularly for the Neopalatial period, and consider the distribution of wall-paintings and exotic stone vessels respectively. Both of the latter two cases are particularly charged forms of Cretan cultural expression and it is at least worth considering that their distribution across the island during the Neopalatial reflect patronage networks, ideological influence and centralised propaganda.

\subsection{A Comparative Approach}

Crete's Bronze Age palatial society emerged on the periphery of an already established network of eastern Mediterranean and Mesopotamian polities, whose character we understand better due to the preservation and decipherment of a rich, if still limited, number of written records. While there were important differences in the distribution of power in different polities, as well as changes over time, in most cases the eastern Mediterranean region was broken up into relatively well-defined areas under the direct rule of a king, and thereafter sometimes under the indirect influence of a 'Great King'. In international correspondence at least, the language used to express this control had become relatively uniform by the $2^{\text {nd }}$ millennium BC (if not before), with the metaphor of the family (both real and fictitious familial relationships between 'sons', 'daughters', 'brothers' etc.), the household estate ('my lands', 'my house', etc.) and the village (friendly relations between neighbours, reciprocal obligations, distrust of parvenus or outsiders) used to articulate more complex geopolitical, hierarchical and economic relationships (e.g. Liverani 2000). The details of these articulations often appeared very different however depending on the audience involved, with a degree of exaggeration accompanying the internal claims of certain kings to international pre-eminence (e.g. Egypt, Hatti). Throughout, the role of other possible players such as semi-independent, temple-based institutions or merchant groups is quite variable. 


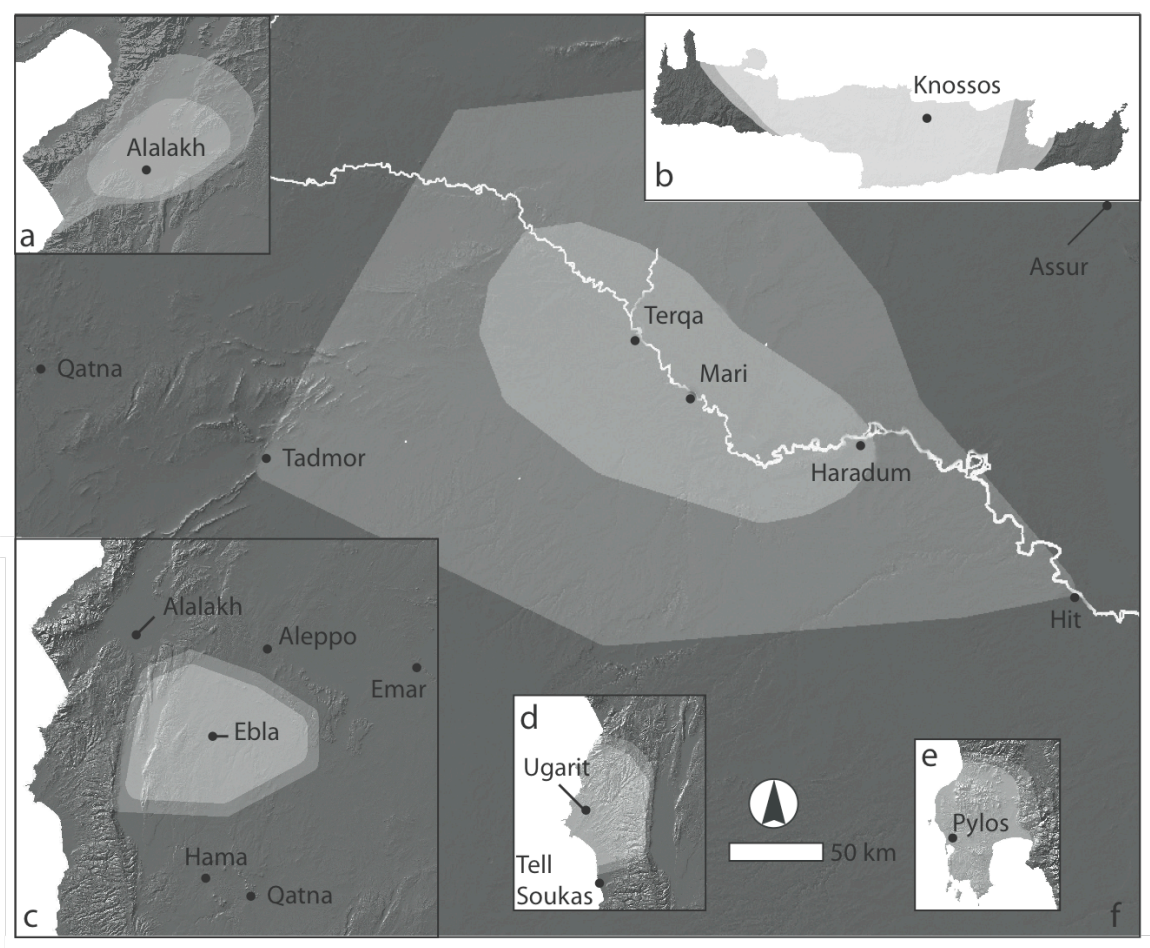

Figure 7. Maps suggesting the likely extent of some MBA-LBA kingdoms based on toponyms: a) MBI-II Mari, b) LMII-IIIA Knossos c) MBI-II Ebla, d) LBII Ugarit, and e) LHIIIB Pylos.

These consistencies, albeit accompanied by some equally interesting contrasts, should encourage us to adopt an explicitly comparative perspective on geopolitical issues wherever possible. For example, we might hope to extract some useful broader perspectives on Cretan political geography by looking at the relationship between capital and territory size in other eastern Mediterranean contexts during the $2^{\text {nd }}$ millennium BC. Occasional written references to (or archaeological evidence for) provincial boundaries for legal administration and customs purposes (Liverani 1990: 33-112; Galàn 2000; Lafont 2000; Casana 2009: 25), both within and between kingdoms, nonetheless make it abundantly clear that the political affiliation of specific places (e.g. key nodes such as settlements, river crossings, oases, roads, major natural landmarks, etc.) and indeed of notional borders were often carefully specified (and fought over). This is true despite the blurring effect of nomadic groups, the occasional evidence for non-contiguous territorial holdings, and the internal ideologies of 'universal control' propagated by larger MB-LBA states (Liverani 1990: 44-50; Casana 2009: 23-26).

\begin{tabular}{|c|c|c|c|}
\hline Capital & Palace & Town & Exclusive Territory? \\
\hline LHIIIB Pylos & 0.7 & $15-20$ & $2-250,000$ \\
\hline LBII Ugarit & 0.7 & $20-25$ & $2-300,000$ \\
\hline $\begin{array}{c}\text { Alalakh (Level } \\
\text { VII/IV) }\end{array}$ & $0.5+?$ & $20-22$ & $200-450,00$ \\
\hline LMII-IIIA Knossos & 0.95 & $40-45$ & $4-600,000$ \\
\hline
\end{tabular}




\begin{tabular}{|c|c|c|c|}
\hline MBI-II Ebla & na & 56 & $5-700,000$ \\
\hline Mari (Zimri-Lim) & 2.4 & $100+$ & $2-8,000,000$ \\
\hline LBA Hattusas & n/a & 180 & $10-15,000,000$ \\
\hline
\end{tabular}

Table 2. Suggested areal extents in hectares for the palace, town and territory of betterdocumented MB-LBA kingdoms in the eastern Mediterranean. Sources: personal calculations and/or drawing upon Bennet 1985: fig.iii.4; Casana 2009; Glatz 2009: fig.1; Heltzer 1976: 2; Lafont 2000: 52-3; Matthiae 1999; Pinnock 2001; Ristvet 2008; Shelmerdine and Bennet 2008: 299-300, fig.12.2; van Soldt 2005: 145).

We can in fact make use of toponymic evidence from the written sources, in several instances, to get a very rough idea of the size of the polity that was associated with a particular capital city (figure 7, table 2). Area measurements of the extent of capital cities and their surrounding kingdoms, certainly cannot be compared in detail, not least because the toponymic evidence is often partial and/or still hotly-debated. We might also expect important variation in the density and character of urban life across the eastern Mediterranean and Middle East, even within the general time-span of the second millennium B.C, so detailed comparison of the size of capitals will also be misleading. However, despite these caveats, the way the capital town sizes in table 1 relate in rough orders of magnitude to overall kingdom size is very informative. Where we have sufficient evidence to make educated guesses, we see that many capitals of MB-LBA eastern Mediterranean kingdoms were probably ruling over inner territories (excluding political alliances and client-kingdoms) that were at least 10,000 times the spatial extent of the capital itself if not frequently more. In partial contrast perhaps are the more closely packed kingdoms of the south-central Levant (e.g. Savage and Falconer 2003): where we have sufficient evidence to consider settlement and kingdom sizes accurately here (rather than merely assuming tell sizes equivalent to those from later occupation phases), the ratio seems slightly smaller, but it remains unclear what impact overall Egyptian suzerainty may have had in discouraging undue political agglomeration in this zone. In the opposite direction, the scaling seems far more extreme for the very largest centres such as Mari and Hattusas, though here too we might claim that the size estimates are somewhat deceptive (see Glatz 2009; Lafont 2000). In any case, the reasons behind this scaling are probably a complex combination of a) the centralised personnel necessary to sustain a political territory of a certain size, given $2^{\text {nd }}$ millennium $B C$ transport and communication technologies, and b) some typical centripetal demographic tendencies associated with territorial expansion. Whatever the reasons and whatever min-max range we choose to play with, these figures still argue that for Neopalatial Knossos, at ca.65+ha the largest known town in Crete by some margin, we might expect an exclusive political territory, spanning most if not all of Crete (an island of 860,000 ha), and perhaps even territories off-island.

\begin{tabular}{|c|c|c|}
\hline Site & Town & $\begin{array}{c}\text { Palatial Building with Central } \\
\text { Court }\end{array}$ \\
\hline Knossos & 65 & $0.95(0.146)$ \\
\hline Phaistos & $<40$ & $0.65-0.8(0.104)$ \\
\hline Malia & $<35$ & $0.82(0.130)$ \\
\hline Galatas & $?$ & $0.24(0.055)$ \\
\hline
\end{tabular}




\begin{tabular}{|c|c|c|}
\hline Zakros & 8 & $0.25(0.037)$ \\
\hline Petras & 2 & $0.15-0.20(0.007) ?$ \\
\hline Gournia & 4 & \\
\hline Chania & $6-8$ & \\
\hline Palaikastro & 13 & \\
\hline $\begin{array}{c}\text { Myrtos } \\
\text { Pyrgos }\end{array}$ & $0.5-1$ & \\
\hline Kommos & 5 \\
\hline Agia Triada & 2 \\
\hline Petras & 2 \\
\hline Mochlos & 2 \\
\hline Archanes & $>2$ \\
\hline Katsambas & 2 \\
\hline
\end{tabular}

Table 1. Suggested area in hectares for major Neopalatial settlements on Crete and the size of those central buildings with a well-preserved central court (court size in brackets). Sources: Whitelaw 2001; D. Puglisi, S. Müller-Celka and V. La Rosa pers.comm (see also Hood and Taylor 1981: fig.285; Myers et al. 1992: fig.44.3; Pelon 1980: pl.28; Pernier and Banti 1951; Rethemiotakis 2002: pl.12; Tsipopoulou 2007).

\subsection{Wall-paintings}

Frescoes are a particularly evocative cultural product of Neopalatial Crete, reflecting both a more elaborative decorative repertoire, more exotic pigments and a more complex set of crafting techniques than any other wall-painting industry in the eastern Mediterranean or Mesopotamia at this time (most recently Bietak et al. 2007; Brysbaert 2008, with further references). Indeed, there was clearly a great deal of prestige associated with this style of room decoration beyond Crete itself, with a large number of examples from the Aegean islands, a later and derivative tradition on the Mycenaean mainland and impressive examples (in many cases, probably made on-site by Cretan or Aegean artisans: Brysbaert 2008) from the palaces of the Levantine coast and Egypt. There is insufficient space here to treat this topic in any detail, but is worth noting that there are important differences in the numbers, subject matter and social context in which these major static works of art were consumed in: (i) Crete, (ii) the rest of Aegean world, and (iii) the wider eastern Mediterranean. For this paper, the key point to note is that each of these three different zones seems to have followed quite different sumptuary behaviour with regard to wall paintings during the equivalent of the Neopalatial (see below).

\begin{tabular}{|c|c|c|c|}
\hline Site & $\begin{array}{c}\text { Bulls/Griffins/ } \\
\text { Object } \\
\text { Processions }\end{array}$ & $\begin{array}{c}\text { Other } \\
\text { Elaborate } \\
\text { Designs }\end{array}$ & $\begin{array}{c}\text { Simple } \\
\text { Designs }\end{array}$ \\
\hline Knossos & $10-20$ & $30-40$ & abundant \\
Archanes & 0 & $2-3$ & present \\
Prasa & 0 & 1 & present \\
Tylissos & 0 & 1 & present \\
Poros- & 0 & 1 & present
\end{tabular}




\begin{tabular}{|c|c|c|c|} 
Katsambas & & & \\
Nirou Chani & 0 & 1 & present \\
Amnisos & 0 & $1 ?$ & present \\
Vathypetro & 0 & 0 & present \\
\hline Agia Triada & 0 & $2-3$ & present \\
Palaikastro & 0 & 1 & abundant \\
Chania & 0 & 1 & present \\
Galatas & 0 & 1 & present \\
Pseira & 0 & 1 & present \\
Zakros & 0 & $1 ?$ & abundant \\
Malia & 0 & $1 ?$ & present \\
Gournia & 0 & 0 & present \\
Koukou & 0 & 0 & present \\
Kephali & 0 & & \\
Mochlos & 0 & 0 & present \\
Myrtos Pyrgos & 0 & 0 & present \\
Zominthos & 0 & 0 & present \\
Phaistos & 0 & $?$ & uncertain \\
\hline
\end{tabular}

Table 3. Elaborate wall-paintings from Neopalatial sites on Crete. (N.B. Sites are listed in two sub divisions: less than about four hours walk from Knossos and more than this (covering ca.6\% and $94 \%$ of the island respectively). The Knossos paintings counted here can only be broadly dated to MMIII-LMIIIA as a group. A question mark in the table indicates uncertainty over the attribution to a more elaborate category. Source: Immerwahr 1990; Blakolmer 2000, with additions.

On Neopalatial Crete, the greatest quantities of surviving wall paintings cluster around Knossos and central Crete (table 3) and it is at Knossos that we see experimentation with a series of potentially highly-charged pictorial scenes evoking cult activity, supernatural animals, unusual relief techniques and bull imagery. On the basis of comparative evidence from other complex societies, Charles Gates argues that the sudden adoption of elaborate pictorial imagery in the Neopalatial period probably reflects the arrival of a new political order that sought to express its new status in an innovative iconographic programme (Gates 2004: 39). Indeed, there is an impressive degree of consistency in this programme, which was responsible, to take just one example, for matching images-in-relief across a full range of different media and artefact sizes, from the portable, repeated image-making of gold signet rings, to répoussé metal vessels or their simulacra in relief-carved and gilded softstone, to full-scale and permanent stucco wall murals (Hallager and Hallager 1995; Bevan 2007: 123; Bietak et al. 2007 and Hood 2005: 55-6 for some perhaps being as early as MMIIIA).

In any case, on Crete, frescoes showing bull imagery (including bull-leaping acrobats), griffins or object-offering processions have only been documented at Knossos, suggesting that they were considered something appropriate at this site, but not elsewhere on the island (see also Bietak et al. 2007). The stucco relief technique also seems to be something strongly associated with Knossos (where it is used for bulls, near life-sized human figures and certain ornamental designs: Blakolmer 2006), but it is interesting that at four other key sites, there is at least one example of a female figure in stucco relief that may well represent an 
effort at direct, but thematically-regulated, Knossian patronage (Immerwahr 1990: At-5, Ch-1, Pa-1, Ps-1; see also Betancourt 2004). Other elaborate frescoes (e.g. miniature scenes, wildlife, marine life, foreign vegetation, ritual symbols) do appear at other sites, by there is still arguably a decline in the elaborateness of subject matter as we move out from north-central Crete, with most of the examples from outlying centres being basic floral and geometric designs.

More generally, this circumscribed distribution of Cretan wall-painting themes is a pattern that suggests not only an island-wide social consensus with respect to appropriate consumption behaviour, but probably also a level of control over the most highly skilled group of craft specialists involved. In a sense, we can see this ultra-skilled group of artisans as a political resource, deployed very sparingly in Crete, but also used, I would argue, in a targeted manner to engage diplomatically with the ruling families of several other eastern Mediterranean polities (see also Bietak et al. 2007 with further references). On Crete, we can also compare this pattern to the similarly concentrated, Knossos-centred distribution of mason's marks on ashlar masonry or the use of gypsum, that are both probably good proxy indicators for the deployment of groups of unusuallyskilled stone masons on dedicated architectural projects (Hood 1987; Chlouveraki 2002; Begg 2004; also Warren 2004: 160). In all three cases, there is a notable concentration of specialist activity in the area within about four hours walk (i.e. an easy return journey in a day) from Knossos that probably indicates both the practicalities of deploying these artisans from a base at Knossos and a desire to reward those elite groups living within the immediate resource hinterland of the palace and town (who were probably supporting the needs of both palace and town more directly: see for comparison, figure $3 \mathrm{a}$, toponym group III and figure 5: area iii; see also Adams 2006). In any case, the consumption of wall-paintings in the wider Aegean is intriguingly different (for their physical and thematic linkage with important harbour sites, see Morgan 2007), with what appears to be much freer production of figurative and pictorial scenes at centres such as Akrotiri on Thera and Agia Irini on Kea (also possibly Miletus on the Anatolian coast), perhaps enabled by a less rigid set of existing norms and a separate group of specialists (e.g. Televantou 2000). Despite this greater apparent freedom, it is only in the post-Neopoalatial period on the Greek mainland that we see the visible take-up of what are perhaps the most directly political fresco images such as bulls (e.g. Immerwahr 1990: Py No. 15-16, Ti No.8).

\subsection{Stone Vessels}

If the wall-paintings from Crete, the rest of the Aegean and at selected sites in the wider eastern Mediterranean suggest possible patterns of more and less directed political influence during the Neopalatial, certain kinds of Cretan stone vessel offer similar potential insight. From the late Prepalatial onwards, stone vessels are relatively common throughout the social hierarchy on Crete, but a small minority also begin to be marked out as of probable higher value, by their more colourful and/or harder material, a much more elaborate shape or a limited amount of added decoration. For the most part, we can link these products to a few of the more important (eventually palatial) centres such as Knossos, Phaistos and Malia (Bevan 2007: 115-9), but during the late Prepalatial to 
Protopalatial, there is nothing inherently exclusive in this extra investment, in terms of materials, tools or skills. In contrast, during the Neopalatial period, a whole class of more ostentatious vessels appears that are made of imported, non-Cretan materials, vividly decorated and/or manufactured with rare tools and techniques (ibid: 120-6).

Table 3 considers the distribution by site of three types of ostentatious Neopalatial stone vessel: (i) foreign imports (mainly Egyptian), (ii) Cretan vessels made from foreign materials (e.g. Egyptian travertine, lapis lacedaemonius, rosso antico, Giali obsidian, Anatolian obsidian and quartz crystal), and (iii) softstone vessels carved with relief scenes (including bull's head rhyta). Not only do these stand out as exclusive products during this period, but we might also think of them as politically-charged for a variety of reasons: (i) there is comparative evidence to suggest that the fanciest stone vessels were one of the classes of object exchanged diplomatically between states or otherwise acquired as political capital (Sparks 2003; Bevan 2007: 124-5, 140-142); (ii) some vessels advertised an ability to access exotic off-island resources, and (iii) the relief carved vessels, unlike most Neopalatial stone vessels, are image-rich artifacts and, as suggested above, were probably part of a iconographic program by the Knossos palace that was repeated in several different media (Bevan 2007: 122-3).

\begin{tabular}{|c|c|c|c||c|c|}
\hline Site & $\begin{array}{c}\text { Imported } \\
\text { Vessels }\end{array}$ & $\begin{array}{c}\text { Imported } \\
\text { Materials }\end{array}$ & $\begin{array}{c}\text { Relief- } \\
\text { carved } \\
\text { Vessels }\end{array}$ & $\begin{array}{c}\text { Total } \\
\text { Exotics' }\end{array}$ & $\begin{array}{c}\text { \% of All } \\
\text { Stone } \\
\text { Vessels? }\end{array}$ \\
\hline Knossos & $(118)$ & $(87)$ & $(37)$ & $(242)$ & $10-20 \%$ \\
\hline Zakros & 5 & $14 ?$ & 2 & 21 & $1-5 \%$ \\
Palaikastro & 3 & 5 & 3 & 11 & $1-5 \%$ \\
Agia Triada & 3 & 2 & 3 & 8 & $1-5 \%$ \\
Archanes & 2 & 4 & 0 & 6 & $1-5 \%$ \\
Myrtos & 2 & 1 & 0 & 3 & $1-5 \%$ \\
\hline Dranos & 1 & 0 & 1 & 2 & $<1 \%$ \\
Malia & 0 & 1 & 0 & 1 & $<1 \%$ \\
Pournia & 0 & 0 & 0 & 0 & $<1 \%$ \\
Mochlos & 0 & 0 & 0 & 0 & $<1 \%$ \\
Phaistos & 0 & 0 & 0 & 0 & $<1 \%$ \\
\hline Katsamba & $(5)$ & 0 & $(1)$ & $(6)$ & $?$ \\
Kalyvia & $(2)$ & $(1)$ & 0 & $(3)$ & $?$ \\
Tylissos & 0 & 1 & 0 & 1 & $?$ \\
Chania & $(1)$ & 0 & 0 & $(1)$ & $?$ \\
\hline & & & & & \\
\hline
\end{tabular}


Table 4. Exotic stone vessels from Neopalatial sites on Crete. (N.B. A number in brackets implies that many of the counted vessels from this site are of likely Neopalatial style, but come from mixed or undated contexts. The horizontal table divisions separate suggested orders of magnitude with respect to the last category, ' $\%$ of all stone vessels'. The 'imported materials'

category only includes vessels of probable Cretan manufacture. The ' $\%$ of all stone vessels category' is only a very rough indication based on the totals suggested in Bevan 2007: 120 n.13).

The distribution of these exotic stone vessels also concentrates heavily at Knossos, even when we try to scale this against the overall number of stone vessels recovered at different sites (table 4). Beyond this centre, certain other towns seem to have been favoured with a few of these objects. For example, Palaikastro and Zakros were harbour sites with far better connections both to the rest of Crete and to the eastern Mediterranean than other east Cretan communities. Along with Chania, they are the centres whose political relationship to Knossos was most likely to fluctuate as the terrestrial conditions of island communication were over-ridden by maritime linkages. Beyond these shorter travel times however, we can also see a diminishing 'metaphorical distance' (for the term, see Falk and Abler 1980: 61-2) that led a few wellconnected occupants of the Palaikastro townhouses and Zakros central building to have much more in common (in terms of some of the exotic objects they possessed, the size and appearance of their homes, etc) with the wealthy and well-connected inhabitants of Knossos than with many of their closer eastern Cretan neighbours or, no doubt, the poorer inhabitants of their own town (see also Betancourt 2004; Platon 2004).

Some of this metaphorical proximity may be the result of patterns of elite emulation within Crete itself (Wiener 1984), but the relatively targeted dissemination of a few image-rich, cultural icons (to go alongside the imports from the eastern Mediterranean that were arriving on the eastern coast) also suggests more active manipulation by those with centralising ambitions. To this portable material culture, we might also add: (i) the comparatively late insertion of a palace into the existing town at Zakros (Platon 1999), (ii) the possible establishment from the Protopalatial onwards of a semi-fortified road network between these two sites (Chryssoulaki 1999) and (iii) the decimation of the Protopalatial peak sanctuaries overlooking the agricultural interior of east Crete in favour of a few Neopalatial sanctuaries with greater maritime connectivity (Watrous 1996: 75-9, 97; Soetens et al. 2002, especially those at Petsophas and Traostalos), all of which suggest careful attention to the eastern end of the island around Zakros and Palaikastro.

\section{Discussion}

Where does all of this computational model-building, cross-cultural comparison and object-based study leave us with respect to Cretan Bronze Age political geography? In many ways, it lends support to an already emerging consensus. The EMI-II Cretan landscape seems to have been one of diversifying settlement and land use strategies but with no sign of sites larger than a few hectares (albeit still with evidence for varying regional settlement trajectories: Driessen 2001b), and it is unlikely that political aspirations consistently extended beyond relatively small valley-sized hinterlands. The following EMIII-MMIA period sees 
intensified patterns of inter-regional interaction in central Crete brought on by settlement nucleation and the rapid urbanization of at least three major centres at Knossos, Phaistos and Malia (if not more). This is a period in which we should expect there to have been more intense competition for land and other resources as well as the first emergence of more far-reaching political institutions.

The appearance of palace buildings, more complex sealing and writing systems in MMI-II probably reflects and enabled the emergence of more formal political territories and a variety of evidence, including regional patterns of script, administration (e.g. Schoep 2001) and pottery (e.g. Knappett 1999) might suggest that, for some if not all of this phase, central Crete comprised three or more polities of roughly equivalent influence (including Knossos, Phaistos and Malia). The direct and indirect sealing of containers, regional palatial pottery styles and the use of other resources (e.g. stone) suggest palatial interest that probably extended to zones beyond their immediate hinterland, but still not particularly distant (in many cases no more than a half-day's walk). It would not be surprising if there were occasional attempts at wider, even pan-Cretan, political unification, given the increasing degree of shared cultural forms, but if so, such moves were not sufficiently successful, enduring or institutionalised to leave their mark in obvious ways within the archaeological record. Stratifying settlement hierarchy in many areas (see Driessen 2001b) and the adoption of a few palace-style designs for central buildings at other sites (e.g. Petras) suggest wider patterns of elite emulation by the most powerful local families. The immediate administrative and economic hinterlands of the palatial centres are likely to have been pretty small (perhaps no more than a day's return journey, see figure 5), and in many ways this maps out the well-known 'city-state' model. However, the intense investment in recognisable cultural products and overseas connections of the Bronze Age Cretan palaces suggest that the political economy rapidly expanded beyond this, and that military power and ideological influence were exerted by one or more centres over longer range.

By MMIII-LMIA, a good argument can be made for more institutionalised forms of Knossian hegemony over much of the island (e.g. Wiener 2007). However, the Neopalatial cannot be treated as a monolithic temporal block, and the varied construction histories at different sites in central Crete arguably indicate shifting configurations of political power. The economic and political situation in LMIB has also been the subject of much debate (e.g. Driessen and Macdonald 1998; Warren 2001), but rarely do such finer chronological distinctions allow us to come to unassailable conclusions at present. The documentary evidence for the following LMII-IIIA period can be used to argue for a major Knossian polity covering a large part of the island, but a combination of the absence of evidence for widespread replica ring impressions, the return of direct object sealing and variation in the documented economic organization of different parts of Crete (Bennet 1985: 238-40; Weingarten 1990: 112-4) all might argue that overall levels of political integration were reduced and/or more uneven than before (especially Driessen 2001a). The pattern in LMIIIB depends on the position taken on the date of the Knossos tablets and the destruction of the Knossos palace (Preston 2008, with further references), but increasing political fragmentation into the Postpalatial period seems very likely. 
Ironically, the above description also remains pretty close in its basic elements to the one suggested by later Classical sources (putting aside ad hominem narratives of King Minos), but has the advantage of at least not assuming this to be true from the outset. More generally, this paper has sought to underpin such narratives with a wider range of evidence and a more formal set of interpretative models, but it concludes by returning to some of the broader theoretical issues that were raised above.

For computational simplicity, the analysis of hierarchical territories in section 3.2 above made two simplifying assumptions with respect to role of demography and physical space as politically-configuring factors: (i) that the size of a settlement relates to its political influence in a straightforward way, and (ii) that this influence decays with travel-time away from the settlement in an equally straightforward fashion. In both cases, we might argue that the simplicity of this model makes it useful to think with, it nonetheless demands a more complex final interpretation. For example, there are clearly important threshold effects in operation that mean the nature of political control shifts in more abrupt, less even, ways as we move: (a) out of the palace and into the urban space around it, (b) beyond into the hinterland throughout which communication might occur within a single day, (c) further afield into areas where travel by strangers becomes inherently riskier, (d) over possible borders and/or into areas whose cultural customs are very different, and (e) towards the edge of the traveller's known universe. Likewise, there are clearly organizing thresholds associated with settlements as they grow: (a) beyond a few hundred (that might require more complex, and often stratified, forms of organization), (b) beyond the existing agricultural capacity of a centre's hinterland (that might require both new agricultural and non-agricultural solutions), and (c) further beyond the social model offered by neighbouring centres of comparable size. The tempo of such population change is also very important, with certain trajectories of demographic boom-and bust (whether via immigration or rapid internal growth) associated cross-culturally with increased political upheaval and innovation (e.g. Goldstone 2002).

Several of the computational and comparative analyses above point quite firmly to these thresholds and the upheaval they might bring: for example the different behaviour of the bottom and top ends of the capital-to-polity size ratios or the abrupt shifts in modelled site hierarchies brought on (only at certain thresholds) by small changes in input parameters. Such theoretical considerations arguably also dovetail with more recent archaeological evidence that favours a more abrupt, rather than gradual, model for the emergence of the Cretan palatial system in the first place (for an overview of the original debate, see Cherry 1984). In any case, it raises the obvious question of how complex societies manage such shifts from, to take just one possible organizational trajectory, a city-state to a state-of-cities to a state-of-states (or the reverse). While there are certainly technical issues associated with the projection of political power at a distance (messaging services, transport networks, fleets etc.), there are usually also important, historically-contingent solutions to the problem of generating the required levels of political self-awareness and cultural cohesion, at a viable scale 
(Turchin 2003: 29-49). In this respect, I would return to the question of heterarchy and suggest that, while the spatial manifestation of hierarchy has been a key concern in this paper, the re-scaling involved in particular episodes of political transition does often take its cultural shape and momentum from the factional, ethnic, or trans-cultural faultlines that criss-cross traditional hierarchies, offering not only alternative conceptual models of how power might be distributed, (however temporary), but also practical mechanisms by which society might reform itself into larger or smaller units. Within Bronze Age Crete, Knossos ultimately seems to have been successful in promoting its own preferred Cretan cosmology and cosmography (e.g. Soles 1995), but at the points of apparent political transition on Crete during the late $3^{\text {rd }}$ to late $2^{\text {nd }}$ millennia, we gain much by eschewing a neat, single narrative and considering the conflicting or converging arguments of multiple social and economic groups. Where both the models and substantive discussion above seek to direct future attention is to the contexts in which these arguments are likely to have been particularly fraught, as well as the analytical scales at which they might most usefully be explored.

\section{Acknowledgements}

My thanks to Fritz Blakolmer, Cyprian Broodbank, Ann Brysbaert, James Conolly, Benjamin Ducke, Claudia Gatz, Carl Knappett, Mark Lake, Colin Nielsen, Krzysztof Nowicki, Frances Pinnock, Laura Preston, Stephen Savage, Rachael Sparks, David Wengrow, Todd Whitelaw and Hai Zhang for discussing many of the topics touched upon in this paper, providing specific bits of information and/or for reading draft versions. I am also grateful to the JMA editors and the anonymous reviewers for their many useful suggestions.

\section{About the Author}

Andrew Bevan is a lecturer at the Institute of Archaeology, University College London. His research interests include landscape archaeology, GIS, value theory, stone vessels, and the political and economic geographies of the Bronze Age eastern Mediterranean.

\section{References}

Adams, E.

2006 Social strategies and spatial dynamics in Neopalatial Crete: an analysis of the north-central area. American Journal of Archaeology 110: 1-36.

Begg, I.

2004 An archaeology of palatial mason's marks on Crete. In Chapin, A.P. (ed.) Charis. Essays in Honor of Sara A. Immerwahr: 1-25. Princeton: American School of Classical Studies at Athens.

Bennet, J.

1985 The structure of the Linear B administration at Knossos. American Journal of Archaeology 89.2: 231-249. 
1990 Knossos in context: comparative perspectives on the Linear B administration of LM II-III Crete. American Journal of Archaeology 94.2: 193-211.

2007 Fragmentary "geo-metry": early modern landscapes of the Morea and Cerigo in text, image, and archaeology. In Davies, S. and J.L. Davis (eds.) Between Venice and Istanbul. Colonial Landscapes in Early Modern Greece: 199-218. Athens: American School of Classical Studies Hesperia Supplement 34).

Betancourt, P.P.

2004 Pseira and Knossos: the transformation of an East Cretan seaport. In Day, L.P., M.S. Mook, and J.D. Muhly (eds.) Crete Beyond the Palaces: Proceedings of the Crete 2000 Conference: 21-28. Philadelphia: INSTAP Academic Press.

Betts, J. H.

1967 New light on Minoan bureaucracy. A re-examination of some Cretan sealings. Kadmos 6: 15-40.

Bevan, A.H.

2007 Stone Vessels and Values in the Bronze Age Mediterranean, Cambridge: Cambridge University Press.

Bietak, M., N. Marinatos, and C. Palyvou

2007 Taureador Scenes in Tell el-Dabca (Avaris) and Knossos, Vienna: Österreichischen Akademie der Wissenschaften.

Blakolmer, F.

2000 The functions of wall painting and other forms of architectural decoration in the Aegean Bronze Age. In Sherratt, E.S. (ed.) The Wall Paintings of Thera. Proceedings of the First International Symposium: 393-412. Piraeus: The Thera Foundation

2006 The Minoan stucco relief: a palatial art form in context. 9th International Congress of Cretan Studies (Elounda, 1-6 October 2001) 1: 9-25.

Brysbaert A.

2008 The Power of Technology in the Bronze Age Eastern Mediterranean. The Case of the Painted Plaster, (Monographs in Mediterranean Archaeology 12), London-Oakville: Equinox.

Cadogan, G.

1994 An Old Palace period Knossian state? In Evely, D., H. HughesBrock and N. Momigliano (eds.) Knossos. A Labyrinth of History: Papers in Honour of Sinclair Hood: 57-68. Oxford: British School at Athens. 
Casana, J.

2009 Alalakh and the archaeological landscape of Mukish: the political geography and population of a Late Bronze Age kingdom. Bulletin of the American School of Oriental Studies 353: 7-37.

Casson, L.

1951 Speed under sail of ancient ships. Transactions and Proceedings of the American Philological Association 82: 136-148.

Cherry, J.F.

1984 The emergence of the state in the prehistoric Aegean. Proceedings of the Cambridge Philological Society 210 (New Series 30): 18-48.

1986 Polities and palaces: some problems in Minoan state formation. In Renfrew, A.C. and J.F. Cherry (eds.) Peer Polity Interaction and Socio-political Change: 19-45. Cambridge: Cambridge University Press.

1987 Power in space: studies of the state. In Wagstaff, J.M. (ed), Landscape and Culture: Geographical and Archaeological Perspectives: 146-72. Oxford: Blackwell.

Chlouveraki, S.

2002 Exploitation of gypsum in Minoan Crete. In Lazzarini, L. (ed.) Interdisciplinary Studies on Ancient Stone. ASMOSIA VI - Proceedings of the Sixth International Conference (Venice, June 15-18 2000): 25-34. Padua: Bottega D'Erasmo.

Chryssoulaki, S.

1999 Minoan roads and guard houses - war regained. In Betancourt, P.P. V. Karageorghis, R. Laffineur and W-D. Neimeier (eds.), Meletemata. Studies in Aegean Archaeology Presented to Malcolm Wiener: 75-85. Liège: Université de Liège (Aegaeum 20).

Chrysoulakis, N., M. Abrams, H. Feidas and D. Velianitis 2004 Analysis of ASTER multispectral stereo imagery to produce DEM and land cover databases for the Greek islands: the REALDEMS project. In Prastacos, P., U. Cortés, J-L. Díaz de León and M. Murillo (eds.) e-Environment: Progress and Challenge: 404-417. Mexico City: Instituto Politécnico Nacional.

Conolly, J. and Lake, M.

2006 Geographical Information Systems in Archaeology. Cambridge: Cambridge University Press.

Crumley, C.L. 
1995 Heterarchy and the Analysis of Complex Societies. Archeological Papers of the American Anthropological Association 7.1: 1-5.

Davis, E.

1995 Art and politics in the Aegean: the missing ruler. In Rehak, P. (ed.), The Role of the Ruler in the Prehistoric Aegean: 11-20. Liège: University of Liège (Aegaeum 11).

Driessen, J.

2001a Centre and periphery: some observations on the administration of the kingdom of Knossos. In Voutsaki, S. and J.T. Killen, Economy and Politics in the Mycenaean Palace States: 96-112. Cambridge: Cambridge Philological Society (Supplement 27).

2001b History and hierarchy: preliminary observations on the settlement pattern of Minoan Crete. In K. Branigan (ed.) Urbanism in the Aegean Bronze Age: 51-71. Sheffield: Sheffield Academic Press.

2002 "The King must die." Some observations on the use of the Minoan court compound. In J. Driessen, J., I. Schoep and R. Laffineur (eds.) Monuments of Minos. Rethinking the Minoan Palaces: 1-14. Liège: Université de Liège (Aegaeum 23).

Driessen, J. and C. Macdonald

1998 The Troubled Island: Minoan Crete before and after the Santorini Eruption, Liège: University of Liège (Aegaeum 17).

Ducke, B. and P.C. Kroefges

2008 From points to areas: constructing territories from archaeological site patterns using an enhanced Xtent model. In Posluschny, A., K. Lambers and I. Herzog (eds). Layers of Perception. Proceedings of the 35th International Conference on Computer Applications and Quantitative Methods in Archaeology (CAA), Berlin, Germany, April 2-6, 2007: 245-251. Bonn: Kolloquien zur Vor- und Frühgeschichte, Vol. 10. Dr. Rudolf Habelt GmbH.

Ehrenreich, R.M., C.L. Crumley and J.E. Levy (eds.)

1995 Heterarchy and the Analysis of Complex Societies, Arlington: American Anthropological Association.

Evans, A.J.

1928 Palace of Minos at Knossos (Volume 2), London: MacMillan.

Evans, T., C. Knappett and R. Rivers

2009 Using statistical physics to understand relational space: a case study from Mediterranean prehistory. In Lane, D., D. Pumain, S. van der Leeuw and G. West (eds.) Complexity Perspectives on Innovation and Social Change: 451-479. Berlin: Springer. 
Evely, R.D.G.

1981 Other finds. In Popham, M.R, (ed.) The Minoan Unexplored Mansion at Knossos, London: Thames and Hudson

Falk, T. and R.F. Abler

1980 Intercommunications, distance, and geographical theory. Geografiska Annaler B 62.2: 59-67.

Fiske, A.P.

2004 Four Modes of Constituting Relationships: Consubstantial Assimilation; Space Magnitude, Time and Force; Concrete Procedures; Abstract Symbolism. In Haslam, N. (ed.) Relational Models Theory: A Contemporary Overview: 61-146. Mahwah: Erlbaum.

Fontenari, S., S. Franceschetti, D. Sorrentino, F. Mussi, M. Pasolli, M. Napolitano and R. Flor

2005 r.walk (GRASS GIS manual page).

Galàn, J.M.

2000 The Egyptian concept of the frontier. In Milano, L., S. de Martino, F. M. Fales and G.B. Lanfranchi (eds.) Landscapes. Territories, Frontiers and Horizons in the Ancient Near East: 21-28. Padua: Sargon.

Gates, C.

2004 The adoption of pictorial imagery in Minoan wall painting: a comparativist perspective. In Immerwahr, S.A. and A.P. Chapin (eds.) Charis. Essays in Honour of Sara A. Immerwahr: 27-46. Athens: American Schools of Classical Studies.

Glatz, C.

2009 Empire as network: spheres of material interaction in later Bronze Age Anatolia. Journal of Anthropological Archaeology 28.2: 127-41.

Gledhill, J.

1988. Introduction: the comparative analysis of social and political transitions. In Gledhill, J., B. Bender and M.T. Larsen (eds.) State and Society: The Emergence and Development of Social Hierarchy and Political Centralization:1-29. London: Routledge.

Goldstone, J.A. 2002 Population and security: how demographic change can lead to violent conflict. Journal of International Affairs 56.1: 1-22.

Graham, S. and J. Steiner

2006 Travellersim: Growing Settlement Structures and Territories with Agent-Based Modelling. In Clark, J.T. and Hagemeister, E.M. (eds) Digital Discovery: Exploring New Frontiers in Human Heritage. Computer Applications and Quantitative Methods in Archaeology. 
Proceedings of the 34th Conference, Fargo, United States, April 2006. Budapest: Archaeolingua.

Grant, E.

1986 Hill-forts, central places and territories. In Grant, E. (ed.) Central Places, Archaeology and History: 13-26. Sheffield: University of Sheffield.

Grundon, I.

2007 The Rash Adventurer: A Life of John Pendlebury, Oxford: Libri.

Hägg, R. and Marinatos, N. (eds.)

1984 The Minoan Thalassocracy. Myth and Reality, Stockholm: Paul Åströms.

Hallager, B.P. and E. Hallager

1995 The Knossian bull - political propaganda in Neopalatial Crete? In Laffineur, R. and W-D. Niemeier (eds.) Politeia. Society and State in the Aegean Bronze Age: 547-56. Liège: Université de Liège (Aegaeum 12).

Hallager, E.

1996 The Minoan Roundel and Other Sealed Documents in the Neopalatial Linear A Administration, Liège: Université de Liège (Aegaeum 14).

Hamilakis, Y.

2002 Too many chiefs? Factional competition in Neopalatial Crete. In J. Driessen, I. Schoep and R. Laffineur (eds.) Monuments of Minos. Rethinking the Minoan Palaces: 179-199. Liège: Université de Liège (Aegaeum 23).

Heltzer, M.

1976 The Rural Community in Ancient Ugarit, Wiesbaden: Ludwig Reichert.

Hood, M.S.F.

1987 Mason's marks in the palaces. In Hägg, R. and Marinatos, N. (eds.) The Functions of the Minoan Palaces: 205-212. Stockholm: Swedish Institute in Athens.

2005 Dating the Knossos frescoes. In Morgan, L. (ed.) Aegean Wall Painting. A Tribute to Mark Cameron: 45-81. London: British School at Athens.

Hood, M.S.F. and W. Taylor

1981 The Bronze Age Palace at Knossos: Plan and Sections, London: British School at Athens. 
Knapp, A.B.

2003 Thalassocracies in Bronze Age eastern Mediterranean trade: making and breaking a myth. World Archaeology 24: 332-47.

Knappett, C.

1999 Assessing a polity in Protopalatial Crete: the Malia-Lasithi state. American Journal of Archaeology 103: 615-639.

2002 Mind the gap: between pots and politics in Minoan studies. In Y. Hamilakis (ed.), Labyrinth Revisited: Rethinking Minoan Archaeology: 167-188. Oxford: Oxbow.

Knappett, C. and I. Schoep.

2000 Continuity and change in Minoan palatial power. Antiquity 74: 365-371.

Krahtopoulou, A. and C. Frederick

2008 The stratigraphic implications of long-term terrace agriculture in dynamic landscapes: polycyclic terracing from Kythera Island, Greece. Geoarchaeology 23.4: 550-585.

Krzyszkowska, 0.

2005 Aegean Seals. An Introduction, London: Institute of Classical Studies.

Lafont, B.

2000 Le Proche-Orient à l'époque des rois de Mari: un monde sans frontières? In Milano, L., S. de Martino, F.M. Fales, and G.B. Lanfranchi (eds.) Landscapes. Territories, Frontiers and Horizons in the Ancient Near East: 49-55. Padua: Sargon.

Lake, D.A.

2009 Hobbesian hierarchy: the political economy of political organization. Annual Review of Political Science 12: 263-83.

La Rosa, V.

2002 Pour une révision préliminaire du second palais de Phaistos. In J. Driessen, I. Schoep, and R. Laffineur (eds.) Monuments of Minos: Rethinking the Minoan Palaces: 71-97. Liège: Université de Liège (Aegaeum 23).

Liverani, M.

1990 Prestige and Interest: International Relations in the Near East ca.1600-1100 B.C., Padua: Sargon.

2000 The Great Powers Club. In R. Cohen and R. Westbrook (eds.), Amarna Diplomacy: The Beginnings of International Relations, 15-27. Baltimore: John Hopkins. 
Marchetti, C.

1994 Anthropological invariants in travel behaviour. Technological Forecasting and Social Change 47: 75-88.

Matthiae, $P$.

1999 Frontières de l'espace urbain: observations sur la forme, l'histoire et l'idéologie. In L. Milano, S. de Martino, F.M. Fales, G.B. Lanfranchi (eds.), Landscapes. Territories, Frontiers and Horizons in the Ancient Near East: 49-54. Padua: Sargon.

McEnroe, J.

1995 Sir Arthur Evans and Edwardian archaeology. Classical Bulletin 71: 3-18.

Melena, J.

1974 Coriander in the Knossos tablets. Minos 15: 133-163.

Morgan, L.

2007 Paintings, harbours and intercultural relations. In Betancourt, P.P., M.C. Nelson and H. Williams (eds.) Krinoi Limenes. Studies in Honor of Joseph and Maria Shaw: 117-129. Philadelphia: INSTAP Academic Press.

Momigliano, $\mathrm{N}$.

2006 Sir Arthur Evans, Greek myths, and the Minoans. In P. Darcque, M. Fotiadis, and 0. Polychronopoulou (eds.), Mythos: La Préhistoire Égéenne du XIX ${ }^{e}$ au XXIe Siècle après J.-C. Table Ronde International, Athènes, 21-23 Novembre 2002, Bulletin de Correspondence Hellénique, Suppl. 46. Paris: École Française d'Athènes: 73-80.

Morris, S.P.

1992 Daidalos and the Origins of Greek Art, Princeton, Princeton University Press.

Myers, J., E.E. Myers and G. Cadogan

1992 Aerial Atlas of Ancient Crete, Berkeley and Los Angeles: University of California Press.

Neimeier, W-D.

2004 When Minos ruled the waves: Knossian power overseas. In Cadogan, G., E. Hatzaki and A. Vasilakis (eds.), Knossos: Palace, City, State: 393-398. London: British School at Athens.

Papadopoulos, J.

2005 Inventing the Minoans: archaeology, modernity and the quest for European identity. Journal of Mediterranean Archaeology 18.1: 87149.

Peatfield, A. 
1987 Palace and peak: the political and religious relationship between palaces and peak sanctuaries. In R. Hagg and N. Marinatos (eds.), The Function of the Minoan Palaces: 89-93. Stockholm: Paul Åström's s Förlag.

Pelon, 0 .

1980 Le Palais de Malia (Volume 5), Paris: Paul Geuthner.

Pendlebury, J.D.S.

1939 The Archaeology of Crete, London: Methuen.

Perlman, P.

1992 One hundred-citied Crete and the "Cretan Politeia". Classical Philology 87.3: 193-205.

Pernier, L and L. Banti 1951 Il Palazzo Minoico di Festòs (Volume 2), Rome: Libreria dello Stato.

Pinnock, F.

2001 The urban landscape of Old Syrian Ebla. Journal of Cuneiform Studies 53: 13-33.

Platon, L.

1999 New evidence for the occupation at Zakros before the LMI palace. In Betancourt, P.P, V. Karageorghis, R. Laffineur and W-D. Neimeier (eds.), Meletemata. Studies in Aegean Archaeology Presented to Malcolm Wiener: 671-81. Liège: Université de Liège (Aegaeum 20).

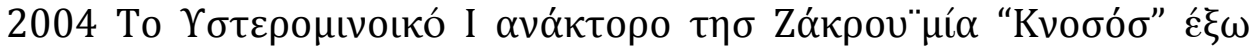

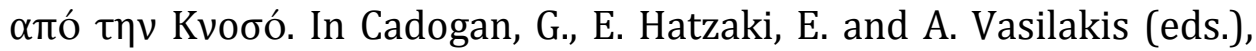
Knossos: Palace, City, State: 381-392. London: British School at Athens.

Preston, L.J.

2008 Mycenaean States. Late Minoan II-IIIB Crete. In C.W. Shelmerdine (ed.), The Cambridge Companion to the Aegean Bronze Age: 310-26. Cambridge: Cambridge University Press.

Renfrew, C. and E.V. Level

1979 Exploring dominance: predicting polities from centres. In Renfrew, A.C. and K.L. Cooke (eds.), Transformations: Mathematical Approaches to Culture Change, 145-67. London: Academic Press.

Rethemiotakis, G.

2002 Evidence on social and economic changes at Galatas and Pediada in the New Palace Period. In Driessen, J. and I. Schoep, and R. Laffineur, (eds.) Monuments of Minos. Rethinking the Minoan Palaces: 55-69. Liège: Université de Liège (Aegaeum 23).

Rethemiotakis, G. and K.S. Christakis. 
2004 Cultural interaction between Knossos and the Pediada region in central Crete, in Cadogan, G. and Hatzaki, E. and A. Vasilakis, A. (eds.), Knossos: Palace, City, State: 159-168. London: British School at Athens.

Rihll, T.E. and A.G. Wilson

1991 Modelling settlement structures in ancient Greece: new approaches to the polis. In J. Rich and A. Wallace-Hadrill (eds.), City and Country in the Ancient World, 59-95. London: Routledge.

Ristvet, L.

2008 Legal and archaeological territories of the second millennium BC in northern Mesopotamia. Antiquity 82: 585-599.

Savage, S.H. and S.E. Falconer

2003 Spatial and statistical inference of Late Bronze Age polities in the southern Levant. Bulletin of the American Schools of Oriental Research 330: 31-45.

Scarry, J.F. and C. Payne

1986 Mississippian polities in the Fort Walton area: a model generated from the Renfrew-Level Xtent algorithm. Southeastern Archaeology 5: 79-90.

Schoep, I.

1999 Tablets and territories? Reintroducing Late Minoan IB political geography through undeciphered documents. American Journal of Archaeology 103: 201-221.

2001 Managing the hinterland: the rural concerns of urban administration. In Branigan, K. (ed.), Urbanism in the Aegean Bronze Age: 87-102. Sheffield: Sheffield Academic Press.

2002 The state of the Minoan palaces or the Minoan palace-state? In J. Driessen, I. Schoep and R. Laffineur (eds.) Monuments of Minos. Rethinking the Minoan Palaces: 15-33. Liège: Université de Liège (Aegaeum 23).

Schoep, I. and Knappett, C.

2004 Dual emergence: evolving heterarchy, exploding hierarchy. In Barrett, J. and P. Halstead (eds.) The Emergence of Civilization Revisited: 21-37. Sheffield: Sheffield Academic Press.

Shelmerdine, C.W. and Bennet, J.

2008 Mycenaean states. Economy and administration, in C.W. Shelmerdine (ed.), The Cambridge Companion to the Aegean Bronze Age: 289-309. Cambridge: Cambridge University Press.

Smith, A.T. 
2003 The Political Landscape: Constellations of Authority in Early Complex Polities, Berkeley: University of California Press.

Smith, M.L.

2005 'Networks, Territories, and the Cartography of Ancient States', Annals of the Association of American Geographers 95.4: 832-49.

Soetens, S., J. Driessen, A. Sarris and S. Topouzi

2002 The Minoan Peak Sanctuary Landscape through a GIS Approach. Archeologia e Calcolatori 13: 161-170.

Soetens, S. and Sarris, A. and Vansteenhuyse, K. and Topouzi, S.

2003 GIS variations on a Cretan theme: Minoan peak sanctuaries, in Foster, K. P. and Laffineur, R. (eds.) Metron: Measuring the Aegean Bronze Age: 483-488. Liège: University of Liège (Aegaeum 24).

Soles, J.S.

1995 The functions of a cosmological center: Knossos in palatial Crete. In R. Laffineur and W-D. Niemeier (eds.), Politeia. Society and State in the Aegean Bronze Age: 405-414. Liège: Université de Liège (Aegaeum 12).

Sparks, R.

2003 Egyptian stone vessels and the politics of exchange (2617-1070 BC). In R. Matthews and C. Roemer (eds.) Ancient Perspectives on Egypt: 39-56. London: UCL Press.

van Soldt, W.

2005 The Topography of the City-State of Ugarit, Münster: Ugarit Verlag.

Televantou, C.

2000 Aegean Bronze Age wall painting: the Theran workshop. In E.S. Sherratt (ed.) The Wall Paintings of Thera: Proceedings of the First International Symposium: 831-843. Piraeus: The Thera Foundation.

Tomkins, $\mathrm{P}$.

2004 Filling in the Neolithic background': social life and social transformation in the Aegean before the Bronze Age. In Barrett, J. and P. Halstead (eds.) The Emergence of Civilization Revisited: 38-63. Sheffield; Sheffield Academic Press.

Tsipopoulou, M.

1997 Palace-centred polities in eastern Crete: Neopalatial Petras and its neighbors. In W.E. Aufrecht, N.A. Mirau and S.W. Gauley (eds.), Urbanism in Antiquity: From Mesopotamia to Crete: 263-77. Sheffield: Sheffield Academic Press. 
2007 The central court of the palace at Petras. In Betancourt, P.P., M.C. Nelson, and H. Williams (eds.) Krinoi Limenes. Studies in Honor of Joseph and Maria Shaw: 49-59. Philadelphia: INSTAP Academic Press.

Turchin, P.

2003 Historical Dynamics: Why States Rise and Fall, Princeton: Princeton University Press.

Warren, P.M.

1984 The palace of Crete in the thalassocracy of Minos. In R. Hägg and N. Marinatos (eds.) The Minoan Thalassocracy: Myth and Reality: 3942. Stockholm: Paul Åström's s Förlag.

2001 Review of Driessen and MacDonald, The Troubled Island: Minoan Crete Before and After the Santorini Eruption, American Journal of Archaeology 105: 115-117.

2004 Terra incognita? The territory and boundaries of the early Knossian state. In Cadogan, G., E. Hatzaki and A. Vasilakis (eds.), Knossos: Palace, City, State: 159-168. London: British School at Athens.

Watrous, L.V.

1996 The Cave Sanctuary of Zeus at Psychro: A Study of Extra-Urban Sanctuaries in Minoan and Early Iron Age Crete, Liège: Université de Liège (Aegaeum 15).

Weingarten, J.

1990 Three upheavals in Minoan sealing administration: evidence for radical change. In T. Palaima (ed.) Aegean Seals, Sealing and Administration: 106-120. Liège: Université de Liège (Aegaeum 5).

Whitelaw, T.

1991 The ethnography of recent rural settlement and land use in North West Keos. In J.F. Cherry, J.L. Davis, and E. Mantzourani (eds.) Landscape Archaeology as Long-Term History: Northern Keos in the Cycladic Islands: 403-454. Los Angeles, UCLA Institute of Archaeology.

2001 From sites to communities: defining the human dimensions of Minoan urbanism. In K. Branigan (ed.) Urbanism in the Aegean Bronze Age: 15-37. Sheffield: Sheffield Academic Press.

2004a Estimating the population of Neopalatial Knossos. In G. Cadogan and E. Hatzaki (eds) Knossos: Palace, City, State: 147-158. London: British School at Athens.

2004b Alternative pathways to complexity in the southern Aegean. In Barrett, J. and P. Halstead (ed.) The Emergence of Civilization Revisited: 232-256. Oxford: Oxbow Books. 
Wiener, M.H.

1984 Crete and the Cyclades in LM I: the tale of the conical cups. In R. Hägg and N. Marinatos (eds.) The Minoan Thalassocracy: Myth and Reality: 17-26. Stockholm: Paul Åström's s Förlag.

2007 Neopalatial Knossos: rule and role, in Betancourt, P.P., Nelson, M.C. and H. Williams (eds.) Krinoi Limenes. Studies in Honor of Joseph and Maria Shaw: 231-42. Philadelphia: INSTAP Academic Press.

Zahavi, Y.

1979 The UMOT, Project, Technical Report for the U.S. Department of Transportation and the German Ministry of Transport (August 1979), Washington and Bonn.

URL: http://www.surveyarchive.org/Zahavi/UMOT_79.pdf 
